\title{
A vállalkozói szemlélet erösítése az egészségügy területén - Az EnterMode gyakornoki program pilot tapasztalatai
}

\author{
Entrepreneurship enhancement in the healthcare - \\ practical experiences of the EnterMode internship pilot program \\ Tóth Tamás ${ }^{1}$, Dr. Lőrincz Orsolya ${ }^{2}$ \\ ${ }^{1}$ Semmelweis Egyetem Digitális Egészségtudományi Intézet \\ 2 Semmelweis Egyetem Egészségügyi Menedzserképző Központ
}

Napjainkban a fokozódó gazdasági verseny következtében a fiataloknak plusz ösztönzökre és eszközökre van szükségük ahhoz, hogy zökkenőmentesen kerüljenek a felsőoktatási intézményekből a munkaerőpiacra, jelentősen felértékelődött a vállalkozási gondolkodásmód és készségek. A gyakorlat egy olyan intézmény lehet, amely képes áthidalni az oktatás és a munkaeröpiac közötti teret és alkalmas a vállalkozói gondolkodásmód erősítésére. Az EnterMode projekt célja egy olyan általánosan alkalmazható és minden szakterületre adaptálható gyakornoki modell kidolgozása, amely hozzájárul a hallgatók vállalkozói gondolkodásmódjának, kompetenciáinak fejlesztéséhez, s emellett programozott keretrendszert biztosít a gyakornokság intézményének, megteremti a kommunikációs felületet a felsőoktatási intézmények és a fogadó szervezetek között. A modell alapja a kihíváson alapuló tanulás, vagyis a gyakornok egy személyre szabott feladatot old meg a fogadóhely mentorának segítségével. A program kiegészítő eszközei egy online játék és egy gyakorlatközösség is. A modell egészségügyi szektorban történő pilot tesztelése Magyarországon a Semmelweis Egyetemen valósult meg, a gyakornokok és a fogadó hely mentorai részéröl is pozitív tapasztalatokkal.

Nowadays, as a result of increasing economic competition, young people need extra incentives and tools to move smoothly from higher education institutions into the labour market. The entrepreneurial mindset and skills have become significantly more valuable. Internship can bridge the gap between education and the labour market and is suitable for strengthening the entrepreneurial mindset. The aim of the EnterMode project is to develop a generally applicable and adaptable internship model that contributes to the development of students' entrepreneurial mindset and competencies, as well as providing a programmed framework for the internship and creating a communication interface between higher education institutions and host organizations. The model is based on challenge-based learning, so that the intern has to solve a personalized task with the help of the host mentor. Additional tools for the program include an online game and a community of practice. Pilot testing of the model in the healthcare sector took place at Semmelweis University in Hungary, the test period has ended with positive experiences from both the interns and the mentors of the host company.

\section{BEVEZETÉS}

Napjainkban a fiataloknak plusz ösztönzőkre és eszközökre van szükségük ahhoz, hogy zökkenőmentesen kerüljenek a felsőoktatási intézményekből a munkaerőpiacra. A globalizáció okozta fokozódó gazdasági verseny következtében felértékelődtek a vállalkozói készségek: a kreativitás, az innováció és a kockázatvállalás, valamint a projektek tervezési és irányítási képességei a célok elérése érdekében. Ugyanakkor a vállalkozói gondolkodásmód és készségek nem születnek velünk: kialakulásukhoz tanulásra és tapasztalatokra van szükség, és akár az oktatási rendszeren belül is elsajátíthatók. Az Európai Unió éppen ezért stratégiai célként túzte ki a kreativitás és az innováció, illetve a vállalkozói szellem erősítését az oktatás és képzés minden szintjén [1] Az oktatás és a vállalkozói szellem fejlesztése közötti kulcsfontosságú kapcsolat a gyakorlat intézménye lehet. Noha a hallgatók gyakorlati tapasztalatokat szereznek és munkahelyi képzést kapnak, a gyakorlat általában nem a vállalkozói készségek fejlesztésére összpontosít. Ezért szükséges mind a felsőoktatási intézményeknek, mind a vállalatoknak együttesen új és innovatív gyakorlati képzési módszereket kidolgozniuk, hogy olyan készségeket nyújtsanak a hallgatók számára, amelyek hasznosak lesznek a munka világában.

A fenti célok megvalósításán egymással együttműködve nyolc EU tagállam tizennégy intézménye dolgozik az Erasmus+ program által finanszírozott nemzetközi EnterMode projekt keretein belül, melynek célja a felsőoktatásban részt vevő oktatók és hallgatók vállalkozói szellemének és ehhez kapcsolódó készségeinek fejlesztése egy általánosan alkalmazható, minden területre adaptálható gyakornoki modell kidolgozásával. A Semmelweis Egyetem mellett négy ország (Görögország, Németország, Olaszország, Szlovákia) egy-egy felsőoktatási intézménye vesz részt a projektben. Az EnterMode egyik eredményterméke a „Gyakornoki modell a vállalkozói gondolkodásmód és kompetenciák elsajátításához", melynek pilot tesztelésére a projektben résztvevő öt felsőoktatási intézményben került sor a 2020/2021es tanévben. Magyarországon a gyakornoki program egészségügyi szektorba történő bevezetését és előkészületeit a 
Semmelweis Egyetem Egészségügyi Közszolgálati Kara menedzselte. Cikkünkben bemutatjuk a gyakornoki modell felépítését és beszámolunk a pilot tapasztalatokról, a hallgatók, ill. a vállalati mentorok visszajelzéseiről, kitérve a COVID19 járvány hatásaira is.

\section{SZAKMAI GYAKORLATOK A MAGYAR FELSŐOKTATÁSBAN}

Magyarországon a felsőoktatási tanulmányok alatti kötelező vagy önkéntes szakmai gyakorlatok általános kereteit a Nemzeti felsőoktatásról szóló 2011. évi CCIV törvény határozza meg, a részleteket pedig a 230/2012. (VIII. 28.) Kormányrendelet a felsőoktatási szakképzésről és a felsőoktatási képzéshez kapcsolódó szakmai gyakorlat egyes kérdéseiről szabályozza. Az egyes képzésekben meghatározott Képzési és kimeneti követelményekben (18/2016. (VIII. 5.) EMMI rendelet, 2. melléklet) előírható kötelező szakmai gyakorlat elvégzése, mely a záróvizsgára bocsátás előfeltétele.

A szabályozás nem tér ki a vállalkozói gondolkodásmód oktatására, annak szintje nagymértékben függ a képzési program által lefedett szakterülettől és ágazatától, valamint az intézményektől. A vállalkozói készségeket illetően az összes felsőoktatási program általános kritériumai és kötelező moduljai a következő: munkaerő-piaci ismeretek, idegen nyelvek alapismerete, a szakmai és pénzügyi információk feldolgozásának alapjai (beleértve az alapvető informatikai ismereteket is), kommunikációs ismeretek.

\section{A VÁLLALKOZÓI GONDOLKODÁSMÓD FEJLESZTÉSE}

Az Európai Unió egyik alapvető célkitűzése a vállalkozói gondolkodásmód (entrepreneurship) fejlesztése, amely az egész életen át tartó tanulás nyolc kulcskompetenciájának egyike is [1]. A vállalkozói készségek alatt nem kizárólag a saját vállalkozás indítására való törekvést értjük, hanem tágabb értelemben a lehetőségek felismerését és kihasználását, az ötletek gyakorlati megvalósítását és a kitűzött célok elérésére való törekvést. Az EU definíciója szerint [2] a vállalkozói kompetencia „egy transzverzális kompetencia, amely az élet minden területén érvényesül: a személyes fejlődés előmozdításától, az aktív társadalmi szerepvállaláson és (akár alkalmazottként, akár önálló vállalkozóként) a munkaerőpiacra való belépésen vagy újra belépésen keresztül a (kulturális, társadalmi vagy kereskedelmi értéket képviselő) vállalkozások indításáig." A vállalkozói gondolkodásmód számos részterületet magába foglal, melyeket az Európai Bizottság Közös Kutatóközpontja (JRC) által kidolgozott EntreComp: The Entrepreneurship Competence Framework foglal egységes keretbe [2]. Az EntreComp keretrendszer három kompetenciaterületet, és azon belül öt-öt, tehát összesen tizenöt részkompetenciát azonosít (1. ábra).

Az EntreComp keretrendszer része egy fejlődési modell is, amely egy referenciát biztosít a készségek fejlesztéséhez. A vállalkozói szemléletmód fejlesztésének nincs egy egységes, lineáris módja, ehelyett az egyes kompetenciákban lehet feljebb lépni és egyre önállóbbá válni. Az EntreComp fejlődési modell négy fö szintet különböztet meg. Az Alapozó szint külső támogatással létrehozott vállalkozói értékeitől elindulva az egyén egyre önállóbbá válik, végül a Szakértői szinten a létrehozott értéknek jelentős hatása van az érintett területre. Fontos, hogy nem cél minden kompetenciaterületen a legmagasabb szint elérése, hanem mindenki az élethelyzetének és a céljainak megfelelően rugalmasan választhatja ki a fejlődési utat.

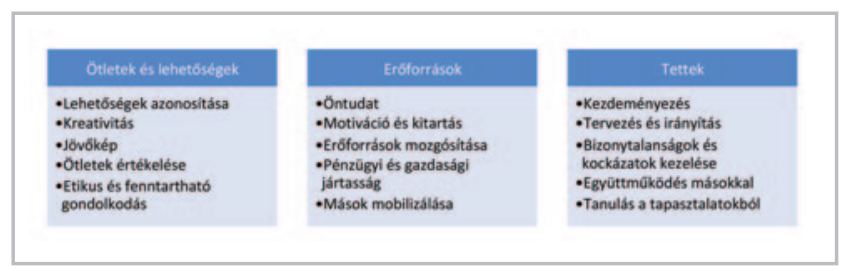

1. ábra

Az EntreComp keretrendszerben meghatározott vállalkozói kompetenciák (Forrás: [2])

\section{AZ ENTERMODE GYAKORLATI MODELL BEMUTATÁSA}

Az EnterMode gyakornoki modell célja többrétű. A hallgatóknak nemcsak a saját tanulmányi területükön szükséges speciális ismeretekkel és készségekkel kell rendelkezniük, hanem általános kreatív, innovációs és vállalkozói készségekkel is. A sikeres és eredményes gyakornoki képzéshez gondos tervezésre és programozásra van szükség, és nem elhanyagolható a gyakornoki képzések szereplőinek összehangolása a szakmai gyakorlat konkrét célkitűzéseivel, tevékenységeivel és várható eredményeivel kapcsolatban.

A céloknak megfelelően az EnterMode gyakornoki modell az alábbi alappillérekre épít:

\section{- Kihíváson alapuló tanulás}

A módszer lényege, hogy a gyakornok egy problémával (kihívással) szembesül, melyre önállóan kell megoldási javaslatot keresnie, és azt megvalósítania. Konkrét útmutatás helyett a vállalati mentor tanácsokkal segíti a munkáját, valamint hozzáférést biztosít a probléma megoldásához szükséges erőforrásokhoz (például háttér dokumentumokhoz, rendszerekhez stb.). A kihíváson alapuló tanulási keretrendszer három kölcsönösen összefüggő szakaszra oszlik, ezek a Bevezető-, a Vizsgálódási- és a Munkafázis. A keretrendszert követve az EnterMode gyakornoki modell is e három szakaszra bontható [3].

A Bevezető (vagy elköteleződési) fázis során történik a hallgatók és a vállalatok párosítása, és a gyakornok a mentorral közösen meghatározza a kihívást. A kihívást úgy kell meghatározni, hogy az releváns legyen a vállalkozói készségek fejlesztése szempontjából, és egyszerre szolgálja a gyakornok fejlődését és segítse a vállalat működését.

A Vizsgálódási szakaszban a gyakornok a mentor segítségével kidolgozza a kihívás megoldásához szükséges konkrét intézkedéseket, elkészíti a munkatervet és azonosítják a szükséges erőforrásokat, információkat. 
A Munkafázisban a gyakornok végrehajtja a kidolgozott tervet. Ebben a szakaszban kiemelten fontos a hallgató fejlődésének és elörehaladásának folyamatos nyomon követése, értékelése, és a rendszeres visszacsatolás a mentortól.

\section{- A vállalkozói gondolkodásmód és készségek elsajá- títását szolgáló tanulási eredmények, az EntreComp keretein belül}

A Cedefop szerint [4] a tanulási eredmények azt fogalmazzák meg, hogy a tanulónak mit kell tudnia, illetve mi az, amit a tanulási folyamat végén képes megérteni és elvégezni. Az EnterMode modellben az EntreComp keretrendszeréből választhatók ki azok a tanulási eredmények, amelyekre a szakmai gyakorlat összpontosít.

\section{- Játékos alapokra helyezés (gamifikáció)}

A játékos alapokra helyezés (gamifikáció) a játéktervezés elemeinek alkalmazását jelenti játékokon kívüli kontextusokban [5], mint például az oktatás. Manapság a szakmai gyakornokok a Z generáció „digitális bennszülöttei”, azaz a technológia végigkíséri az életüket. Általában szeretnek azonnal visszajelzést, díjakat és más játékelemeket kapni, így a gamifikáció hatékony eszköz lehet számukra. Az EnterMode projekt keretében kidolgozásra került egy online játék, amely hozzájárul a vállalkozói gondolkodásmód és készségek fejlesztésére. A játék az EntreComp 15 kompetenciájából hat fejlesztésére irányul: kreativitás; a jövőkép; az erőforrások mozgósítása; a lehetőségek azonosítása; a bizonytalanságok és kockázatok kezelése; és a másokkal való együttműködés.

\section{- Inkubáció a vállalkozói szellem és kultúra fejlesztésére}

A fogadó szervezetek erőforrásokat, képzést és oktatási támogatást nyújtanak a náluk gyakornokoskodó hallgatóknak, ami felfogható egyfajta inkubációként. A mentorok inkubátorként nem mondják meg pontosan a gyakornokoknak, hogy mit kell tenniük, hanem önálló kutatásra, felfedezésre ösztönzik öket, segítik, hogy saját maguk tanulhassanak.

\section{- Gyakorlatközösség (community of practice) kialakítása}

Wenger szerint [6] „a gyakorlatközösségeket olyan emberek alkotják, akik ugyanazon tevékenység iránt érdeklődnek vagy éreznek elköteleződést, és egymással rendszeresen kommunikálva megtanulják, hogyan lehet ezt a tevékenységet jobban csinálni”. Az EnterMode Gyakorlatközössége a virtuális gyakorlatközösségek európai internetes platformján, a DISCUSS-on müködik.

\section{- Értékelés és visszajelzés}

A gyakornok által elért eredmények nyomon követésére, mérésére az EnterMode többféle eszközt dolgozott ki, melyek közül a legfontosabbak az alábbiak:

- Vállalkozói kompetenciák önértékelése: a hallgató a gyakorlat előtt és után is értékeli a saját kompetenciáit egy kérdőív segítségével, ezáltal lehetőség van a fejlődés mérésére.

- Elvárások és tapasztalatok értékelése: a program szereplői (hallgató, vállalat, felsőoktatási intézmény) a gya- korlat kezdete elött és után kérdőív segítségével rögzíti előzetes elvárásait, valamint az elvárások teljesülését.

- Gyakornoki terv: rögzíti többek között a kihívást, az elérendő célokat, a fejlesztendő kompetenciákat és a vállalat által nyújtott erőforrásokat.

- Gyakorlati napló: heti összefoglalót nyújt a gyakornok által elvégzett feladatokról, az esetleges nehézségekről, problémákról.

- A mentor által készített végső jelentés: a mentor összefoglalja a program fő tanulságait és eredményeit.

\section{PILOT TAPASZTALATOK}

$\mathrm{Az}$ EnterMode gyakorlati modell pilot tesztelésére Magyarországon a 2020/2021-es tanévben került sor, melynek bevezetését és előkészületeit a Semmelweis Egyetem Egészségügyi Közszolgálati Kara menedzselte.

A gyakornokokat fogadó szervezetek felkérés alapján kerültek kiválasztásra. A felhívás után összeált azon vállalatok listája, akik szívesen alkalmazzák a javasolt EnterMode módszertant annak érdekében, hogy nyissanak egy újfajta szemléletmód irányába és fejlesszék önmagukat, s gyakornokaik vállalkozói kompetenciáit. A fogadóhelyek - bár mind egészségügyi beállítottságúak - eltérő szervezeti formával rendelkeztek, volt közöttük start-up, magánklinika és alapítvány is. A projekt hangsúlyt fektetett a vállalati mentorok felkészítésére is, akik felkészítő tréningen ismerkedhettek meg az EnterMode gyakorlati modellel és az abban rejlö lehetőségekkel.

A kiválasztott 3 gyakornok eltérő, de számára izgalmas és kihívásokkal teli feladatot kapott. Az egyik nyertes pályázó egy új radiológiai képelemző eszköz kifejlesztésében és annak marketing stratégiájában vett részt, a másikuk szülészet- és nőgyógyászati betegtájékoztatás különböző kommunikációs csatornákon megvalósuló fejlesztésébe kapcsolódott be, a harmadik hallgató pedig a nonprofit szektor kommunikáció és adományszervezési területéhez csatlakozott a daganatos gyerekek segítése érdekében.

A COVID-19 okozta járványügyi helyzet az EnterMode gyakornoki programot is érintette: a jelentkezőkkel folytatott interjúk és a vállalati mentorok felkészítése is telekonferencia rendszeren keresztül történt, és a gyakornokok közül kettő teljes mértékben, a harmadik részben virtuális módon teljesítette a gyakorlatát. A projekt konzorciuma külön útmutatót dolgozott ki a modell rendkívüli helyzethez való adaptálására, ezzel is segítve a vállalatokat. Az előzetes félelmek ellenére a távmunka hatékonynak bizonyult, és mind a mentorok, mind a hallgatók eredményesnek értékelték a gyakornokságot.

A hallgatók visszajelzései egyértelműen pozitívak, izgalmasnak és hasznosnak tartják a programot, mely során gyakorlati tudást szereztek, sokat fejlődtek, továbbá átfogóbb képet kaphattak leendő szakmájukról. A gyakornokok a következőkröl számoltak be:

- Kipróbálhatták magukat valós körülmények között.

- Új területeket ismerhettek meg (pl. a nonprofit szektor müködése). 
- Képzéseken, workshopokon vehettek részt.

- A feladat teljesítésével fejleszthették vállalkozói készségeiket, például a kreativitásukat.

- Új kapcsolatokat építhettek.

- Sikerélmény volt számukra, hogy munkájuk eredménye beépült a vállalat müködésébe.

A gyakornoki modellt implementáló fogadóhelyek is pozitív visszajelzéseket adtak.

- Hasznosnak értékelték, hogy a kiválasztási folyamat során megismerhették a jelentkezőket, és több hallgató közül választhattak.

- A gyakornokok gyorsan képessé váltak az önálló munkára és új nézőpontot hoztak a szervezetbe.

- Az egyik fogadóhely korábban nem dolgozott gyakornokkal, de a jó tapasztalatok hatására a program keretein belül újabb hallgató fogadására is vállalkozott.

- Lehetőséget adott az új vezetőknek vezetői készségeik fejlesztésére, a szervezet bővülésével új dimenziók nyíltak meg a munkaszervezést illetően.

- A közösségi médiában megjelent posztok és egyetemi hírek segítettek a fogadóhelyek nyilvános arculatának és jó hírének javításában.

\section{ÖSSZEFOGLALÁS}

Magyarországon a felsőoktatási tanulmányok alatti kötelező vagy önkéntes szakmai gyakorlatok általános kereteit a Nemzeti felsőoktatásról szóló 2011. évi CCIV törvény határozza meg. Habár a szabályozásba foglalt kötelező modulokon [munkaerő-piaci ismeretek, idegen nyelvek alapismerete, szakmai és pénzügyi információk feldolgozásának alapjai (beleértve az alapvető informatikai ismereteket is), kommunikációs ismeretek] keresztül elsajátított készségek sikeresen alkalmazhatók vállalkozásoknál, hiányzik a vállalkozói gondolkodásmód és ismeretek kötelező modulként való megjelenése. Ez a modul magában foglalhatja az üzleti fejlődéshez szükséges alapvető jogi-, menedzsment- és közgazdasági ismereteket, érdekes jó gyakorlatokkal, amelyek inspirálhatják az új generációt. A gyakorlatok tartalmát, követelményeit és a hallgatók feladatait a felsőoktatási intézmények szabadon meghatározhatják, azonban a szakmai gyakorlatok kiszervezése következtében, a felsőoktatási intézményekben nem alakult ki a vállalkozói gondolkodásmód és készségek támogatása. A felsőoktatáshoz kapcsolódó gyakornoki képzések során gyakran hiányzik az egyeztetés a küldő fél (felsőoktatási intézmény) és a fogadó fél (vállalat) között a szakmai gyakorlat konkrét célkitüzéseivel, tevékenységeivel és várható eredményeivel kapcsolatban, pedig e célok összehangolása mindkét fél számára előnyös lenne.

Az EnterMode projekt keretében megvalósult gyakornoki program sikeresnek bizonyult. A szakmai gyakorlatok sikerének két legfontosabb tényezője van: a mentorálás és hallgatók elégedettsége [8]. $E$ tekintetben mind a hallgatók, mind a fogadó szervezetek részéről pozitív visszajelzések érkeztek. A hallgatókat a szakmai gyakorlatok során egyebek mellett a készségek és feladatok változatossága, az autonómia és maga a munka tette elégedetté. A fogadó szervezetek sokat profitáltak a toborzási és kiválasztási metódusból és nagyon elégedettek voltak a gyakornokok munkájával, annyira, hogy a hallgatók közül többen állandó munkatárssá váltak. A gyakornoki modell leginkább azoknak a kisebb szervezeteknek volt hasznos, akiknek korábban még nem volt tapasztalatuk gyakornokokkal, a szervezet bővülése a munkamegosztás újfajta szervezési szemléletet követelt tőlük, aminek köszönhetően fejlödtek. Az EnterMode modell végső céljai, azaz a vállalkozói gondolkodás erősítése, a programozott gyakornokság és a felek közötti cél egyeztetés és kommunikáció erősítése teljesültek, a program az egészségügyi szektort tekintve is alkalmazhatónak tünik.

A pilot mintaként szolgálhat azoknak a szervezeteknek, akik szeretnék létrehozni saját gyakornoki programjukat. Az EnterMode modell teljes egészében vagy akár részleteiben is adaptálható, testreszabható a vállalatok igényeinek megfelelően. A zárást követő kerekasztal beszélgetés és a visszajelző kérdőívek alkalmazása lehetőséget nyújtott a tudás, a tapasztalatok és ötletek kölcsönös megosztására. A program során hazai szinten értékes, új kapcsolatok jöttek létre a fogadó szervezetek és a felsőoktatás között.

\section{IRODALOMJEGYZÉK}

[1] Európa Tanács: A Tanács ajánlása az egész életen át tartó tanuláshoz szükséges kulcskompetenciákról. (2018) (2018/C 189/01) [Megtekintés dátuma: 2021. 05.12]

[2] Bacigalupo M, Kampylis P, Punie Y: EnterComp: The Enterpreneurship Competence Framework. (2016) Luxembourg: Publication Office of the European Union; EUR 27939 EN; http://doi.org/10.2791/593884

[3] Nichols M, Cator K, Torres M: Challenge Based Learner User Guide. (2016) Redwood City, CA: Digital Promise.
[4] Cedefop: Defining, writing and applying learning outcomes: a European handbook. (2016) Luxembourg: Publications Office. http://doi.org/10.2801/566770

[5] Deterding S, Khaled R, Nache LE,,Dixon D:. Gamification: Toward a Definition. (2011) https://doi.org/10.1145/1979742.1979575

[6] Wenger E: Communities of Practice and Social Learning Systems: the Career of a Concept. (2010) In: Blackmore C. (eds) Social Learning Systems and Communities of Practice. Springer, London http://doi.org/10.1007/978-1-84996-133-2_11 
[7] EnterMode: Gyakornoki modell a vállalkozói gondolkodásmód és kompetenciák elsajátításához. (2019) Kassai Müszaki Egyetem

\section{A SZERZŐK BEMUTATÁSA}

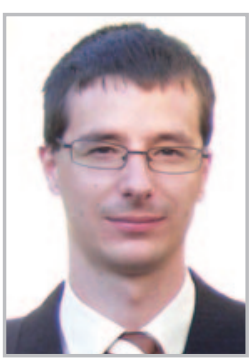

Tóth Tamás a Semmelweis Egyetem Digitális Egészségtudományi Intézetben dolgozik tanársegédként. Doktori kutatásának fókuszában a digitális technológiák, elektronikus egészségügyi megoldások betegekre, szakem-

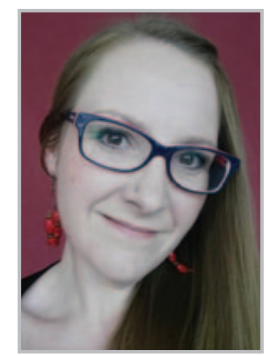

Dr. Lörincz Orsolya 1983-ban született Budapesten. A Pécsi Tudományegyetem Általános Orvostudományi Karán 2012-ben végzett általános orvosként. 2018-ban a Budapesti Corvinus Egye-
[8] Narayanan V, Olk P: Determinants of Internship Effectiveness: An Exploratory Model. (2010) Academy of Management Learning \&Education, 9 (1), 61-80. https://doi.org/10.5465/AMLE.2010.48661191 berekre és az orvos-beteg kapcsolatra gyakorolt hatásának vizsgálata áll. 2009-ben a Semmelweis Egyetemen informatikus egészségügyi menedzser diplomát szerzett. A Neumann János Számítástudományi Társaság Orvosbiológiai Szakosztályának tagja. temen szerzett közgazdász diplomát. Jelenleg az Országos Gyógyszerészeti és Élelmezés-egészségügyi Intézet és a Semmelweis Egyetem Egészségügyi Menedzserképző Központjának munkatársa.

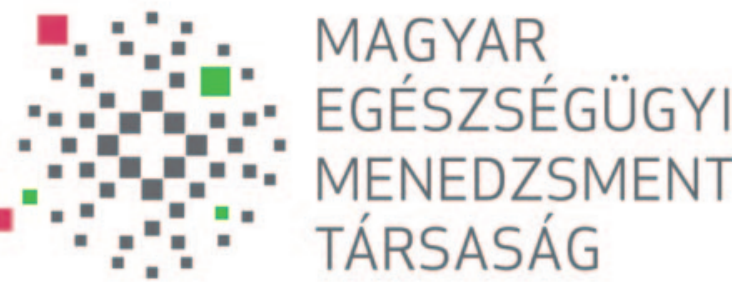

www.memt.hu

- SZAKMAI ESEMÉNYEK, KONFERENCIÁK, MÜHELYBESZÉLGETÉSEK, KÉPZÉSEK SZERVEZÉSE ÉS MEGVALÓSÍTÁSA

DIGITÁLIS EGÉSZSÉGÜGYI TECHNOLÓGIÁK FEJLESZTÉSÉNEK TÁMOGATÁSA

- KUTATÁS - FEJLESZTÉSI TEVÉKENYSÉGEK TÁMOGATÁSA
- STRATÉGIAI TANÁCSADÁS

SZAKMAI KIADVÁNYOK KÉSZÍTÉSE

TARTALOMMENEDZSMENT

- HíRLEVÉLSZOLGÁLTATÁSOK

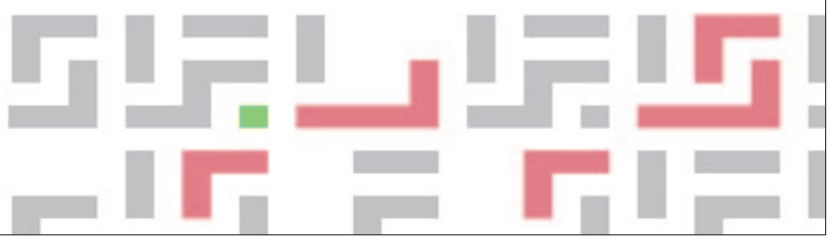

